medRxiv preprint doi: https://doi.org/10.1101/2020.08.23.20180513; this version posted August 25, 2020. The copyright holder for this preprint (which was not certified by peer review) is the author/funder, who has granted medRxiv a license to display the preprint in perpetuity. It is made available under a CC-BY-NC 4.0 International license.

\title{
3D Printed N95 Equivalent for PPE Shortages: The Kansas City Mask
}

2 Shiv Dalla $\mathrm{MS}^{1}$, Brandon Bacon $\mathrm{MD}^{2}$, Jack Ayres BS ${ }^{1}$, Stephen Holmstead BS ${ }^{3}$, Alan J. Ahlberg

$5 \quad{ }^{1}$ University of Kansas Medical Center

$6 \quad{ }^{2}$ University of Missouri-Kansas City, Truman Medical Center

$7 \quad{ }^{3}$ Unaffiliated

8

9

10

11

12

13 Corresponding author information:

14 Shiv Dalla MS

$152200 \mathrm{~W} 47^{\text {th }} \mathrm{Pl}$, Apt 304

16 Westwood, KS 66205

17 Phone: (316) 250-9933

18 sdalla@kumc.edu

19 
ABSTRACT

21 Introduction

During the COVID-19 pandemic, the shortage of personal protective equipment (PPE)

23 was well-reported and discussed, not only in the healthcare sector but across all of society as the

24 demands for PPE skyrocketed. As hospitalizations for COVID-19-related illness continue to

25 increase, many recent reports indicate the supply of PPE is persistently and significantly less

26 than the demand. These PPE shortages encouraged communities of 3D printing experts and

27 hobbyists to design and distribute homemade, 3D-printed PPE, including N95 mask substitutes.

28 The mask presented, the Kansas City Mask (KC Mask), is one such product which was created

29 from the maker community in partnership with local physicians and hospitals. This report

30 discusses the design, manufacturing, and validation of the $\mathrm{KC}$ Mask design and its usage in the

31 COVID-19 pandemic as well as future use as stopgap PPE.

$33 \underline{\text { Methods }}$

34 The KC Mask was adapted from a similar design called the Montana Mask. Mask components

35 were 3D printed and assembled then fit tested by qualitative fit testing (QLFT) at Truman

36 Medical Center in Kansas City, MO as a proof of concept.

$\underline{\text { Results }}$

39 The QLFT was successful and the KC Mask was approved for use by pandemic response

40 administration staff at the hospital. Fortunately, the KC Mask has not required wide utilization,

41 however, because supply chains for Kansas City area hospitals have, at the time of this

42 publication, not yet been exhausted by the pandemic. 
medRxiv preprint doi: https://doi.org/10.1101/2020.08.23.20180513; this version posted August 25, 2020. The copyright holder for this preprint

(which was not certified by peer review) is the author/funder, who has granted medRxiv a license to display the preprint in perpetuity.

It is made available under a CC-BY-NC 4.0 International license .

\section{Conclusion}

45 The results of Truman Medical Center's approval of the KC Mask are promising for this N95

46 stop-gap substitute. Although further analysis and study is needed for this design, persistently

47 increasing caseloads and PPE shortages necessitate an urgent dissemination of these preliminary

48 results. The authors do not advocate for the KC Mask as a replacement of traditional N95 masks

49 or other PPE but do endorse the KC Mask as a stopgap measure, proven to be effective in

50 situations of dire PPE shortage based on CDC guidelines.

51

52 


\section{INTRODUCTION}

54 Background

As the first eight months of 2020 have shown, the novel coronavirus, named "SARS-

56 CoV-2," represents a critical and serious threat to public health. ${ }^{1}$ Highly contagious and virulent,

57 the virus has been reported to cause severe respiratory problems in infected patients and was

58 declared a pandemic by the World Health Organization (WHO) in March. ${ }^{1}$ As the potential

59 global economic impact of the pandemic came to light, ${ }^{2}$ the healthcare industry faced an

60 overwhelming challenge: the adequate supply of appropriate personal protective equipment

$61 \quad(\mathrm{PPE}) .^{3}$

$63 \quad$ PPE Shortages

64 The shortage of PPE is well-reported and discussed, not only in the healthcare sector, but

65 across all of society as the demands for PPE skyrocketed. ${ }^{3-5}$ Unfortunately, as hospitalizations

66 for COVID-19-related illness continue to increase, recent reports indicate the supply of PPE is

67 persistently and significantly less than demand. ${ }^{6}$ Even though the supply has risen since the

68 beginning of the pandemic, experts predict that the supply is insufficient for predicted caseloads

69 and it may take years in order for stockpiles to be fully replenished. ${ }^{7}$ PPE shortages have been

70 shown to contribute to viral spread within healthcare environments and in the general

71 community. This, of course, leads to increased societal harm and ultimately, preventable death.

72 Of concern, these rates are shown to be significantly greater in communities of color and low

73 socio-economic status. ${ }^{8}$ 
medRxiv preprint doi: https://doi.org/10.1101/2020.08.23.20180513; this version posted August 25, 2020. The copyright holder for this preprint (which was not certified by peer review) is the author/funder, who has granted medRxiv a license to display the preprint in perpetuity.

$\underline{\text { 3D Printed Alternatives }}$

3D printing experts and hobbyists, known as "makers" identified the challenge posed by

78 PPE shortages and sought to create homemade masks, face shields and even gowns to mitigate

79 the issue. Makers with access to 3D printers were encouraged to produce stop-gap PPE that

80 could be used in clinical environments. The widespread availability and cost-effective nature of

$813 \mathrm{D}$ printing lead to an incredible phenomenon of collaboration among makers to develop various

82 PPE products. The flexibility and robust applications of 3D printers was leveraged into a

83 uniquely useful tool to this end. Face shields, face masks, and strap adjustment devices became

84 particularly popular products.

85 The mask presented, the Kansas City Mask (KC Mask), is one such product which was

86 created from the maker community in partnership with local physicians and hospitals. This report

87 discusses the design, manufacturing, and validation of the Kansas City mask design and its usage

88 in the COVID-19 pandemic as well as future usage as stopgap PPE.

90 METHODS

$91 \quad$ Mask Design

92 The Kansas City Mask is a stop-gap, reusable, face mask substitute for level 1, level 3, or

$93 \quad$ N95 face masks consisting of two 3D printed parts. 
medRxiv preprint doi: https://doi.org/10.1101/2020.08.23.20180513; this version posted August 25, 2020. The copyright holder for this preprint (which was not certified by peer review) is the author/funder, who has granted medRxiv a license to display the preprint in perpetuity.

It is made available under a CC-BY-NC 4.0 International license.

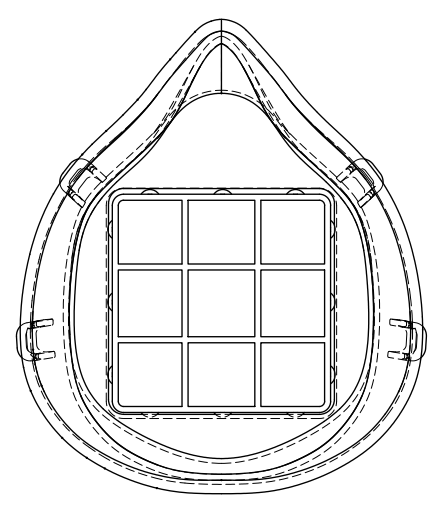

$\downarrow$
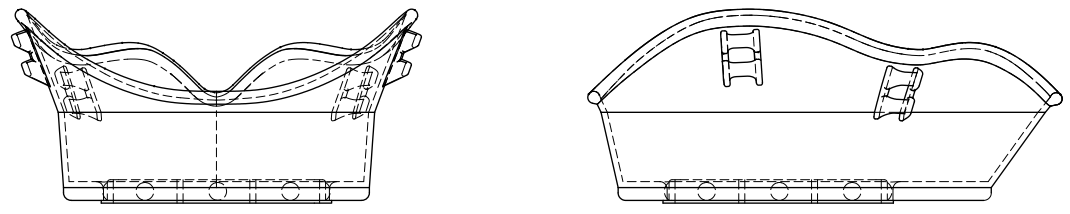

97 As shown in Figure 1, the main component of the mask is the contoured surface that makes contact with the user's face. On the external surface of the main component there is a $60 \mathrm{~mm} x$

$9960 \mathrm{~mm}$ square hole where the second component, the filter holder, a $60 \mathrm{~mm} \times 60 \mathrm{~mm}$ grid, will snap into place, holding in the space filter material. The mask accepts most fabrics as filter material. In this study, Halyard H600 sterilization wrap, which is commonly used in hospitals for

102 packaging of sterilized surgical instruments and N99 rated, was used. goal of this redesign was to address some shortcomings of the Montana Mask, ${ }^{9}$ namely ease of breathing and fit. The Montana Mask has a smaller filter cross sectional area, making it more difficult to breath. The design is additionally enhanced by the dipping process explained in its respective section. 
medRxiv preprint doi: https://doi.org/10.1101/2020.08.23.20180513; this version posted August 25, 2020. The copyright holder for this preprint (which was not certified by peer review) is the author/funder, who has granted medRxiv a license to display the preprint in perpetuity.

\section{Design and 3D Printing}

110 exported to an STL file for compatibility with hobbyist 3D printer workflows. These workflows

111 use a "slicer" software to convert the universal STL file into GCODE that is specific to an

112 individual 3D printer. Two combinations of slicer and printer were tested. The Cura slicer was

113 used to prepare GCODE for a Lulzbot Taz5, and PrusaSlicer was used to prepare GCODE for a

114 Creality CR-10S. Masks were printed in a variety of filaments including Polylactic acid (PLA),

115 Polyethylene terephthalate glycol (PET-G), and Thermoplastic polyurethane (TPU). PLA was

116 selected for further fit testing for its ease of use, cost effectiveness, and ability to be safely

117 thermoformed to a user's face in hot water. For masks submitted to QLFT, the print settings

118 shown in Figure 2 were used. 


\section{Figure 2: Print Settings}

\begin{tabular}{|l|l|}
\hline Select Print Setting & Value \\
\hline Layer Height & $0.25 \mathrm{~mm}$ \\
\hline Wall Line Count & 4 \\
\hline Top/Bottom Layers & 4 \\
\hline Infill Density & $20 \%$ \\
\hline Printing Temperature (Nozzle) & $205^{\circ} \mathrm{C}$ \\
\hline Printing Temperature (Build Plate) & $60^{\circ} \mathrm{C}$ \\
\hline
\end{tabular}

Dipping is an optional process in which liquid rubber is added to the rim of the mask

124 which makes contact with the wearer's face. This allows for a better seal as well as increased 125 comfort. FlexSeal rubberized sealant was used in testing due to its lack of respiratory hazards.

126 An optional dipping tray model is provided to help with this process. The goal is to coat the rim

127 of the mask that will be touching the users face. Alternatively, weather stripping can be utilized

128 for the same purpose, though this reduces ease of sterilization once applied.

After the mask is dipped, it can be molded to the wearer's face by increasing the 130 temperature of the mask above the glass transition point of the material. For PLA, the easiest

131 way to do this is to submerge the mask (including the filter holder, but without any filter

132 material) in hot water $\left(\sim 60^{\circ} \mathrm{C}\right)$. This allows for the PLA to become soft enough to mold, but the

133 structure is maintained. The wearer should submerge the PLA for $\sim 10$ seconds and mold it to fit

134 their face. This can be repeated until a good and comfortable fit is achieved. 
medRxiv preprint doi: https://doi.org/10.1101/2020.08.23.20180513; this version posted August 25, 2020. The copyright holder for this preprint

(which was not certified by peer review) is the author/funder, who has granted medRxiv a license to display the preprint in perpetuity.

It is made available under a CC-BY-NC 4.0 International license.

$137 \quad$ Fit Testing

138

The KC Mask was fit tested at Truman Medical Center in Kansas City, MO with the help

139 of resident physician Dr. Brandon Bacon and the facilities staff. A standard qualitative fit test

140 (QLFT) was performed using standard saccharin solution aerosol protocol.

141

142 Usage

143 Elastic straps are used to secure the mask to the wearer's face. In Figure 3, instructions

144 for assembly and use of the mask are discussed. This image is distributed alongside the mask as

145 instructions for the user. These instructions include how to mold the mask, place the straps, and

146 insert the filter. Sterilization of the mask is done using a Sani wipe or dilute bleach solution.

147 Filters are meant to be used only once, or can be re-sterilized per institutional protocol.

148 
medRxiv preprint doi: https://doi.org/10.1101/2020.08.23.20180513; this version posted August 25, 2020. The copyright holder for this preprint (which was not certified by peer review) is the author/funder, who has granted medRxiv a license to display the preprint in perpetuity.

It is made available under a CC-BY-NC 4.0 International license .

\section{Figure 3: Assembly and Usage Instructions}

\section{Kansas C ity 3D Printed Mask Ca re Instructions}

If PPE is not available, thismask is provided as a last resort. Use a certified medical N95 mask if available.

The mask is made of a plastic called polylactic acid (PLA). It is a rigid plastic that becomesmalleable above $65 \mathrm{C}$.

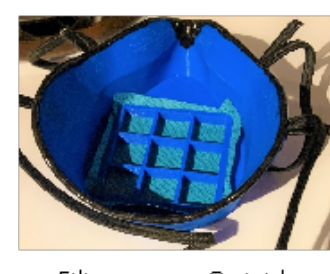

For straps

Filter

Cartridge

\section{Peparing mask foruse:}

Before using your ma sk for the first time, sa nitize the mask. Thisc an be done with orange top Sani-cloth wipesor a diluted solution of bleach*.

Mold it comfortably to yourface:

1. Warm water to barely simmering $-65-70^{\circ} \mathrm{C}$ elsius.

2. Keeping the fitter cartridge in place, dip the edge of the mask (that sts on yourface) in the water $\sim 10$ seconds.

3. Remove the mask from the water

4. Quickly wipe the water off the mask, apply it to yourface, and mold the mask to your face

5. Repeat these sepsuntil the mask makesa comfortable seal around your mouth and nose.

Place trapsand adjus:

1. Use two $1 / 4^{\prime \prime}$ W ela tic headbands (c ut in half) OR two $18^{\prime \prime} \mathrm{L} \times 3 / 8^{\prime \prime} \mathrm{W}$ ela sic waist band material.

2. Insert the band into the strap connec tor from back to front (see pic ture)

3. Loop the band back through the space between the two connectors (see picture). This allowsyou to a djust the tightness once the mask isplaced on your face

4. Repeat teps 1-3 on the other side

5. Repeat steps $1-5$ for the second pair of strap connectors.

\footnotetext{
clean waterand readied for use
}

Make and insert filter:

1. Cut a $3^{\prime \prime} \times 3^{\prime \prime}$ square using a filter material. Examples an N95 mask with broken elastic $s$ sterile wrap from the $\mathrm{OR}$, or any other filtration material available. Avoid materialswith fibergla ss asthey are dangerousto inhale.

2. Lay the $3^{\prime \prime} \times 3^{\prime \prime}$ filter square and center the filter cartridge on the ingide of the mask

3. Push the filter cartidge into place from inside the mask with the flange on the inside

4. Note: Push near the edges where the support struts are loc ated to reduce risk of breaking the cartridge

\section{After using the mask:}

1. Wipe down all surfaces of the mask with an orange sani wipe or submerge in the bleach solution for 12-15 minutes after each day of use. The filter can be sterilized per local protoc ol or discarded and replaced.

\section{CAUTION!}

$\forall$ The PLA material hasa low melting point and will melt if left athigh temperatures, such a sin a car on a hot day. Protect your mask by keeping it indoors when it is hot outgde and a way from warm machinery.

$\forall$ If your mask breaks, discard the mask and do not continue using it. If a seal cannot be created, then the mask will not be able to protectyou.

\section{*\#each solution for sanitizing masks:}

All equip ment that comes into contact with mucousme mbranes must re ce ve e ither High Leve I Disinfection (Hம) orsterilization before use on anotherpatient. HD c an be achieved by soaking in a dilute sodium hypoc hlorite solution for a minimum of 12 minutes. This solution c an easily be prepared from commercially available household bleach, nearty always available as a $5.25 \%$ $6.15 \%$ solution ( 52,500 ppm $-62,500$ ppm).

The dilute solution for roaking thise quip ment should be prepared as a 1:20 dilution, mxing 1 part household ble ach to 20 partstap water, rendering approximately $2,500 \mathrm{ppm}-3,000 \mathrm{ppm}$ concentration. M $\times 200 \mathrm{ml}$ of bleach $(5.25 \%-6.15 \%$ sodium hyp oc hlorite) in 4 litersw ater. If the ble ach ise ither more or le ss concentrated, alter the dilution accordingly to achieve the ppm noted above.

CAUTION: Hyp ochlorite so lutionsmust not mx with a mmonia solutionsasthe mixture $c$ an produc e toxic chlorine gas in mixing this solution, it isadvised to e r on the slightly more conc entrated side (i.e., to greaterthan the minimum concentration needed) due to degradation of the hypochlorite that occurs overtime. especially in open c ontainers

After so aking 12-30 minutes the equip ment should be rinsed with 
medRxiv preprint doi: https://doi.org/10.1101/2020.08.23.20180513; this version posted August 25, 2020. The copyright holder for this preprint (which was not certified by peer review) is the author/funder, who has granted medRxiv a license to display the preprint in perpetuity.

It is made available under a CC-BY-NC 4.0 International license .

\section{$\underline{\text { Study Design }}$}

IRB approval was not requested nor required for this study because this was a proof of

154 concept and quality improvement initiative. Although further analysis and study to prove

155 efficacy is required, the purpose of this study and report is to discuss the design, manufacturing, 156 and validation of the KC Mask concept.

\section{RESULTS}

Several dozen masks were distributed to Truman Medical Center. As a proof of concept,

Dr. Brandon Bacon donned the mask and performed a standard qualitative fit test (QLFT). The

161 QLFT was successful and the KC Mask was approved for usage by pandemic response

162 administration staff at the hospital as a stop-gap measure in the event that standard N95 PPE

163 became depleted. The KC Mask was not widely utilized, however, because Truman Medical

164 Center maintained adequate PPE supply chains up to the time of this publication.

\section{DISCUSSION}

The results of Truman Medical Center's approval of the KC Mask are promising for this

168 N95 stop-gap substitute. Although qualitative fit testing is less rigorous than quantitative fit

169 testing, it has been shown to be highly correlated with proper mask seal and fit. ${ }^{10}$ More extensive

170 testing can and should be done, including quantitative fit testing and design modification.

171 In light of the current persistent PPE shortages, as well as potential shortages in the case

172 of increasing caseloads, it is important to consider PPE and N95 alternatives, particularly those

173 outside of the main supply chain of conventional PPE. This is critical for a number of reasons,

174 the most obvious being stopgap PPE in health care settings in situations of dire shortages. 
medRxiv preprint doi: https://doi.org/10.1101/2020.08.23.20180513; this version posted August 25, 2020. The copyright holder for this preprint (which was not certified by peer review) is the author/funder, who has granted medRxiv a license to display the preprint in perpetuity.

It is made available under a CC-BY-NC 4.0 International license .

175 Additionally, alternative PPE such as that described in this report can create access to PPE for

176 additional groups without compromising current PPE supply channels. This could include

177 providing N95 mask alternatives to individuals living with somebody who tests positive for

178 COVID-19, a situation in which more readily available cloth or surgical masks would not be

179 sufficient. This is especially important when considering that shortages of PPE are particularly

180 common in minority communities and communities of low socio-economic status. ${ }^{8}$ As stated by

181 Brown Emergency Medicine (Rhode Island) physician Dr. Megan Ranney, "Whether it's the

182 elderly, minority populations, populations affected by structural racism and historical injustice,

183 those are the very groups that have the most difficult time getting adequate PPE for their

184 workers." ${ }^{8}$ PPE shortages are largely seen as one of the biggest drivers of the racial divide in the

185 COVID-19 pandemic in which infection rates and hospitalization rates disproportionately favor

186 African American and Latino populations. ${ }^{8}$ Accordingly, technology such as that which is

187 presented in this report has the potential to uniquely help our country's most vulnerable.

188 Although further analysis and study is needed for this design, persistently increasing

189 caseloads and PPE shortages necessitates an urgent dissemination of these preliminary results.

190 The authors do not advocate for the KC Mask as a replacement of traditional N95 masks or other

191 PPE but do endorse the KC Mask as a stopgap measure, proven to be effective in situations of

192 dire PPE shortage.

194 CONCLUSION

195 The results of Truman Medical Center's approval of the KC Mask are promising for this N95

196 alternative. Although further analysis and study is needed for this design, persistently increasing

197 caseloads and PPE shortages necessitates an urgent dissemination of these preliminary results. 
medRxiv preprint doi: https://doi.org/10.1101/2020.08.23.20180513; this version posted August 25, 2020. The copyright holder for this preprint (which was not certified by peer review) is the author/funder, who has granted medRxiv a license to display the preprint in perpetuity.

It is made available under a CC-BY-NC 4.0 International license.

198 The authors do not advocate for the KC Mask as a replacement of traditional N95 masks or other

199 PPE but do endorse the KC Mask as a stopgap measure, proven to be effective in situations of

200 dire PPE shortage.

201

202

\section{REFERENCES}

203 1. Sohrabi C, Alsafi Z, O'Neill N, et al. World Health Organization declares global

204 emergency: A review of the 2019 novel coronavirus (COVID-19). Int J Surg.

$205 \quad 2020 ; 76: 71-76$.

206 2. Mike-Hana Fongang M, Ahmadi N. The Impact of a Pandemic (COVID-19) on the Stock

207 Markets : A Study on the Stock Markets of China, US and UK [Student thesis]2020.

208 3. Jacobs A, Richtel M, Baker M. 'At War With No Ammo’: Doctors Say Shortage of

209 Protective Gear Is Dire. The New York Times. 2020/03/19/T15:58:44-04:00, 2020; Health.

210 4. Jessop ZM, Dobbs TD, Ali SR, et al. Personal Protective Equipment (PPE) for Surgeons

211 during COVID-19 Pandemic: A Systematic Review of Availability, Usage, and

$212 \quad$ Rationing. Br J Surg. 2020.

213 5. Mandrola J. [CoViD-19 and PPE: some of us will die because of the shortage.]. Recenti

$214 \quad$ Prog Med. 2020;111(4):183.

215 6. Fassett GM, Camille. Supply of PPE for medical workers begins to run low again as

216 COVID-19 spikes in US. chicagotribunecom. 2020.

217 7. Pulver D, Wedell K, Mansfield E. Despite warnings, the US wasn't prepared with masks

218 for coronavirus. Now it's too late. USA TODAY. 2020.

219 8. Dunn L, Fitzpatrick S. Few N95 masks, reused gowns: Dire PPE shortages reveal

$220 \quad$ COVID-19's racial divide. NBC News. 2020. 
medRxiv preprint doi: https://doi.org/10.1101/2020.08.23.20180513; this version posted August 25, 2020. The copyright holder for this preprint (which was not certified by peer review) is the author/funder, who has granted medRxiv a license to display the preprint in perpetuity.

$2219 . \quad$ Richardson DM. Montana Mask. In:2020:https://www.makethemasks.com/.

222 10. Hon CY, Danyluk Q, Bryce E, et al. Comparison of qualitative and quantitative fit-testing 223 results for three commonly used respirators in the healthcare sector. $J$ Occup Environ Hyg. 2017;14(3):175-179. 

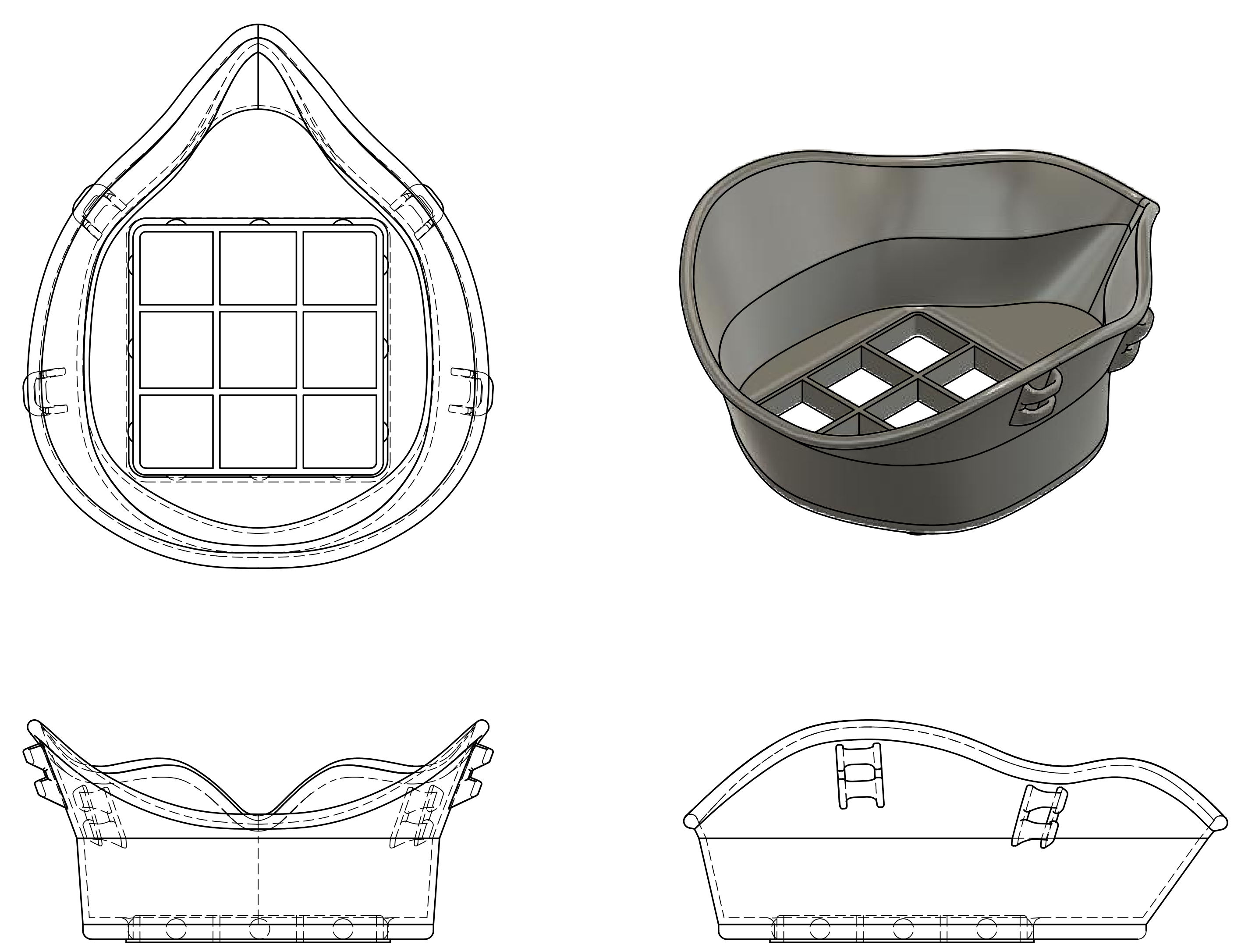